\title{
Tingkat Kepuasan Karyawan Perusahaan Swasta dalam Pelayanan Jaminan Sosial Tenaga Kerja (Jamsostek)
}

\author{
Level of Satisfaction of Private Company Employees in Social Security Service
}

\author{
Matias Siagian
}

\section{Departemen Ilmu Kesejahteraan Sosial Fakultas Ilmu Sosial dan Ilmu Politik Universitas Sumatera Utara}

\begin{abstract}
Abstrak
Penelitian ini berbentuk penelitian deskriptif yang mengkaji masalah pelaksanaan program Jaminan Sosial Tenaga Kerja (Jamsostek) sebagai hak karyawan. Penelitian ini bertujuan mengetahui tingkat kepuasan karyawan yang bermukim di desa Mulyorejo, sebuah desa industri, dalam pelayanan Jamsostek khususnya Jaminan Pemeliharaan Kesehatan, Jaminan Kecelakaan Kerja, dan Jaminan Kematian. Sampel penelitian terdiri dari 70 keluarga karyawan peserta Jamsostek. Data dikumpulkan dengan menggunakan kuesioner dan dianalisis dengan menggunakan statistik deskriptif. Tingkat kepuasan karyawan diukur dengan skala likert. Hasil penelitian menyimpulkan, secara umum pelayanan Jamsostek belum memuaskan. Sosialisasi belum memuaskan karyawan. Dari tiga pelayanan yang diteliti, hanya satu yang memuaskan, yaitu Jaminan Kematian, sedangkan pelayanan Jaminan Pemeliharaan Kesehatan dan Jaminan Kecelakaan Kerja kurang memuaskan. Pelayanan administrasi ternyata lebih buruk daripada pelayanan teknis.
\end{abstract}

Kata kunci: jaminan kecelakaan kerja, jaminan kematian, jaminan pemeliharaan kesehatan, Jamsostek

\footnotetext{
Abstract

This research is descriptive study which reviewing problem of social securities program implementation as employee's right. The objective of this study is to examine the employee satisfaction level who live in Mulyorejo, an industral village, in social security services particulary health insurance, accident insurance, and death benefit. Research sample involved $70 \mathrm{em}$ ployee's families as social security member. Research data was collected by questionaires and analysed by descriptive statistic. Satisfaction level of employee measured by likert scale. This research have led to some discoveries: generally, social security services has not satisfying the members. The program socialization has not been made employee satisfied. Only death benefit among other services that given satisfying service. Health insurance and accident insurance did not quite satisfying. Finally, ad-
}

ministration service was really worse than technical service.

Keywords: accident insurance, death benefit, health insurance, social security

\section{Pendahuluan}

Karyawan atau tenaga kerja memiliki kedudukan strategis dalam proses produksi barang dan jasa dalam perusahaan. Walaupun merupakan salah satu dari beberapa faktor produksi, karyawan tidak wajar disejajarkan dengan faktor produksi lain, seperti mesin, bangunan, modal, alat angkutan, dan lain-lain. Karyawan memiliki kedudukan strategis sebab merupakan eksekutor rencana yang ditetapkan managerial. Oleh karena itu kesejahteraan karyawan dan keluarganya wajar diperhatikan agar dapat menyumbangkan tenaga secara optimal dalam proses produksi. ${ }^{1}$

Harus diakui, perhatian terhadap karyawan atau pekerja masih dirasa kurang, padahal peran sertanya dalam pembangunan sangat strategis. Akibatnya, tingkat kesejahteraan pekerja atau karyawan masih tergolong rendah. Termasuk di dalamnya masalah kesehatan pekerja. Pembangunan bidang kesehatan merupakan bagian integral dari pembangunan kesejahteraan sosial. ${ }^{2}$

Perhatian dan perlindungan tenaga kerja seharusnya dilakukan secara optimal. Hal ini berkaitan erat dengan perkembangan dunia industri di era globalisasi yang demikian pesat dan mengakibatkan persaingan yang makin ketat di sektor industri, baik industri besar,

Alamat Korespondensi: Matias Siagian, Departemen Ilmu Kesejahteraan Sosial, FISIP Universitas Sumatera Utara, Jl. Prof. A. Sofyan No. 1 Kampus USU Padang Bulan Medan 20155, Hp.081260861963, e-mail: s.siagian@ymail.com 
menengah, maupun kecil. Persaingan tersebut bahkan sudah berkembang menjadi persaingan antarnegara. Inti persaingan antarnegara tidak lagi dilandasi oleh jenis dan jumlah ilmu pengetahuan dan teknologi yang digunakan karena iptek yang digunakan dapat saja dibeli. Persaingan antarnegara saat ini justru lebih dilandasi oleh persaingan kualitas sumber daya manusia yang mampu mengoperasikan iptek secara optimal. Sebagai faktor penentu dalam memenangkan persaingan, perlindungan tenaga kerja menjadi sangat penting agar tenaga kerja dapat menyumbangkan keahliannya dalam proses produksi melalui operasionalisasi ilmu pengetahuan dan teknologi. ${ }^{3}$

Kajian mendalam terhadap kebutuhan manusia melalui diagnosis dan penilaian sosial antara lain memperoleh informasi bahwa para buruh merupakan komunitas yang membutuhkan pelayanan melalui intervensi sosial. Oleh karena itu, mereka memerlukan mekanisme tersendiri dalam berbagai pelayanan, terutama dalam pendidikan dan kesehatan. Buruh, seperti halnya masyarakat miskin lainnya pada umumnya tidak memiliki akses terhadap pelayanan pendidikan dan kesehatan melalui mekanisme pasar. Dalam keadaan seperti ini, penciptaan mekanisme khusus dalam bentuk jaminan sosial merupakan aktivitas kreatif yang harus dilakukan untuk memenuhi kebutuhan para buruh. ${ }^{4}$

Dalam buku berjudul Introduction to Social Work and Social Welfare, Charles Zastro mengemukakan setidaknya ada empat usaha atau pelayanan yang dilakukan dalam mewujudkan kesejahteraan sosial, yaitu: personal services (seperti bimbingan perorangan, bimbingan kelompok, rehabilitasi, maupun terapi sosial), protection services (seperti perlindungan konsumen, perbaikan hukum agar benar-benar melindungi masyarakat, pelayanan perumahan maupun pelayanan kesehatan), information services (seperti pemberian konsultasi, informasi bagi konsumen, pendidikan, pelayanan perpustakaan, konsultasi keuangan), dan care services (seperti perawatan anak, perawatan pekerja, program kesejahteraan umum dan program jaminan sosial). ${ }^{5}$

Dalam upaya menciptakan kesejahteraan sosial bagi masyarakat, setiap negara memiliki sistem tersendiri yang dinamakan sistem jaminan sosial nasional. Pemikiran sistem jaminan sosial pertama kali dikemukakan secara mendalam dan kritis oleh Otto von Bismark pada tahun 1883 sehingga dinobatkan menjadi Bapak Sistem Jaminan Sosial. Sistem jaminan sosial nasional suatu negara dituangkan dalam berbagai peraturan perundang-undangan yang masing-masing dikaitkan dengan kelompok sasar yang dilindungi, seperti asuransi kesejahatan untuk PNS/TNI/POLRI, Jamkesmas untuk masyarakat umum, khususnya masyarakat miskin, maupun jaminan sosial tenaga kerja (Jamsostek). 6

Istilah jaminan sosial selanjutnya dikembangkan di
Amerika Serikat dan dicantumkan dalam The Social Security Act tahun 1935. Pada saat itu, konsep jaminan sosial diarahkan untuk mengatasi masalah-masalah pengangguran, manula, orang-orang sakit dan anak-anak korban depresi ekonomi. Meskipun penyelenggaraan jaminan sosial di negara-negara maju belakangan ini mengalami perubahan, namun pada dasarnya penyelenggaraan jaminan sosial tetap dipahami sebagai bentuk nyata perlindungan negara terhadap rakyatnya. ${ }^{7}$

Memperoleh jaminan sosial merupakan hak konstitusional warga negara. Pasal $28 \mathrm{H}$ ayat (3) UUD 1945 menegaskan: Setiap orang berhak atas jaminan sosial yang memungkinkan pengembangan dirinya secara utuh sebagai manusia yang bermartabat. Lebih lanjut Pasal 34 ayat (2) UUD 1945 menegaskan: Negara mengembangkan sistem jaminan sosial bagi seluruh rakyat dan memberdayakan masyarakat yang lemah dan tidak mampu sesuai dengan martabat kemanusiaan. ${ }^{8}$

Adapun Jamsostek diatur dalam Undang-Undang Republik Indonesia Nomor 3 Tahun 1992. Pada Pasal 4 ayat (1) UU tersebut ditegaskan bahwa Jamsostek adalah program nasional yang wajib dilakukan oleh setiap perusahaan bagi tenaga kerja yang melakukan pekerjaan di dalam hubungan kerja. Selanjutnya Pasal 6 Ayat (1) menegaskan, bahwa pelayanan Jamsostek mencakup Jaminan Kecelakaan Kerja (JKK), Jaminan Kematian (JK), Jaminan Hari Tua (JHT), dan Jaminan Pemeliharaan Kesehatan (JPK) ${ }^{9}$

Dengan diundang-undangkannya Jamsostek, pelayanan Jamsostek tersebut menjadi hak normatif atau hak yang dilindungi hukum bagi karyawan dan keluarganya. Ada tiga pihak yang bertanggung jawab dalam pelaksanaan Jamsostek, yaitu: perusahaan tempat karyawan bekerja, PT. Jamsostek sebagai BUMN yang dihunjuk pemerintah sebagai pelaksana Jamsostek, dan mitra kerja yang dihunjuk dan ditetapkan oleh PT Jamsostek, seperti rumah sakit, klinik, apotik, optik dan lain-lain. Mitra kerja inilah yang menjadi ujung tombak pelaksanaan Jamsostek.

Perusahaan berkepentingan secara langsung dengan kesejahteraan pekerja dan keluarganya. Oleh karena itu, perusahaan wajib menyejahterakan pekerja dan keluarganya. Salah satu cara untuk meringankan beban pihak pengusaha dalam melaksanakan kewajiban untuk memberikan tunjangan kecelakaan, pemeliharaan kesehatan dan jaminan di hari tua bagi para pekerja adalah dengan kebijakan para pengusaha mengikutsertakan pekerja di perusahaan dalam program Jamsostek. ${ }^{10}$

Pertanyaan yang cukup menarik adalah apakah dengan diberlakukannya Undang-Undang tentang Jamsostek, karyawan sudah merasakan manfaatnya? Kepala Kantor Wilayah I PT Jamsostek H. Mas'ud Muhammad mengemukakan bahwa partisipasi perusahaan dalam pelaksanaan program Jamsostek bagi para karyawannya di Wilayah 
Nanggroe Aceh Darussalam, Sumatera Utara, dan Sumatera Barat masih sangat memprihatinkan. Hal ini terbukti dari jumlah tenaga kerja yang mencapai 9,3 juta jiwa, sementara jumlah peserta Jaminan Pemeliharaan Kesehatan (JPK) meliputi peserta lajang 4.951 orang, kawin 88.725 orang, keluarga 218.489 orang, dan tertanggung (seluruh yang masuk JPK) sebanyak 356.725 orang. ${ }^{11}$

Jika dikaji lebih dalam tentang partisipasi perusahaan dalam pelaksanaan program Jamsostek, seperti dikemukakan oleh Kepala Kantor Wilayah I PT Jamsostek H. Mas'ud Muhammad, jumlah perusahaan yang ada di Sumatera Utara misalnya mencapai 11.000 , sedangkan jumlah pekerja mencapai 5 juta orang, pekerja tersebut sebanyak satu juta orang buruh di sektor formal, sedangkan empat juta orang di sektor informal, hingga saat ini hanya 376.000 pekerja formal di Sumatera Utara yang terdaftar sebagai peserta Jamsostek, sedangkan 624.000 orang belum menjadi peserta Jamsostek. Kondisi pekerja di sektor informal jauh lebih mengkhawatirkan lagi, empat juta pekerja tidak menjadi peserta Jamsostek. ${ }^{11}$

Kesenjangan antara jumlah perusahaan dan pekerja dengan peserta Jamsostek memunculkan pemikiran untuk mendirikan institusi alternatif penyelenggara Jamsostek, antara lain berupa Badan Layanan Umum oleh Pemerintah Daerah Provinsi Sumatera Selatan. Terobosan ini didasarkan pada pemikiran akan tanggung jawab Pemerintah Daerah atas kesejahteraan masyarakatnya sesuai dengan tuntutan otonomi daerah sebagaimana diatur dalam Undang-Undang Nomor 32 Tahun 2004 tentang Pemerintahan Daerah. Bagaimanapun juga, kesejahteraan masyarakat merupakan isu sentral dalam penyelenggaraan pemerintahan, baik oleh pemerintah pusat maupun pemerintah daerah. ${ }^{12}$

Buruknya penyelenggaraan Jamsostek berakar dari praktik monopoli. Jamsostek dilaksanakan sesuai dengan peraturan perundang-undangan yang berlaku. Saat ini aturan yang dimaksud adalah Undang-Undang Nomor 3 Tahun 1992 tentang Jaminan Sosial Tenaga Kerja. Pasal 4 Ayat (3) Undang-Undang tersebut mengatur persyaratan dan tata cara penyelenggaraan program Jamsostek yang dilaksanakan melalui Peraturan Pemerintah No. 14 Tahun 1993 dan Peraturan Pemerintah Nomor 36 Tahun 1995 dengan menetapkan PT Jamsostek sebagai badan tunggal penyelenggara Jamsostek. Kondisi ini menuntut reformasi hukum dalam rangka penyelenggaraan Jamsostek. ${ }^{13}$ Sebagai badan penyelenggara jaminan sosial, PT Jamsostek mempunyai misi untuk memberikan pelayanan yang terbaik bagi pesertanya. Pelayanan yang semakin baik dapat dijadikan sebagai salah satu tolak ukur keberhasilan program Jamsostek karena hal tersebut dapat menyadarkan peserta bahwa program Jamsostek merupakan program perlindungan yang sangat dibutuhkan. ${ }^{14}$

Jaminan sosial adalah bentuk perlindungan pemerin- tah terhadap tenaga kerja, yang pelaksanaannya dilatarbelakangi oleh berbagai faktor, seperti meningkatnya peranan tenaga kerja baik secara kuantitas maupun kualitas; meningkatnya penggunaan teknologi di berbagai sektor kegiatan usaha; dan semakin tingginya risiko yang mengancam keselamatan, kesehatan dan kesejahteraan tenaga kerja. ${ }^{15}$

Tuntutan implementasi jaminan sosial bagi tenaga kerja di Indonesia semakin urgen mengingat mayoritas tenaga kerja di Indonesia di sektor swasta adalah mereka yang berpendidikan rendah (SMP dan sederajat $66,75 \%)$. Kondisi ini menggambarkan betapa rendahnya kualitas mayoritas tenaga kerja Indonesia di sektor swasta. Keadaan menuntut intervensi pihak luar, dalam hal ini pemerintah melalui program jaminan sosial, sehingga mereka dapat menikmati kondisi hidup yang layak berdasarkan kemanusiaan. Namun, hingga saat ini negara belum mampu mengembangkan program jaminan sosial sebagaimana mestinya. ${ }^{16}$

Program asuransi kesehatan keluarga miskin masih bergumul dengan berbagai masalah. Data tidak akurat, sosialisasi tidak optimal, pelayanan tidak gratis penuh, pungutan liar, penolakan, pelayanan buruk, antre lama, ruang sempit, tindakan tidak segera, dokter terlambat, dan rumah sakit menolak adalah beberapa masalah yang menghilangkan hak penduduk miskin. ${ }^{17}$

Berdasarkan mekanisme pelaksanaan program Jamsostek, pelaksanaan Jamsostek secara umum dapat dibagi ke dalam tiga tahap, yaitu sosialisasi, pendaftaran, dan pelayanan. Sosialisasi merupakan proses pengenalan program Jamsostek kepada calon karyawan atau karyawan perusahaan. Sosialisasi semestinya dilaksanakan saat perekrutan karyawan atau sejak seseorang diterima menjadi karyawan. Sosialisasi harus mampu menjadikan karyawan benar-benar memahami program Jamsostek, khususnya menyangkut hak dan kewajibannya. Dengan demikian, pihak yang melakukan sosialisasi tersebut haruslah orang-orang yang menguasai program Jamsostek. Jika perusahaan tidak memiliki orang yang mampu melakukan sosialisasi secara baik, perusahaan dapat bekerja sama dengan pihak PT Jamsostek. ${ }^{18}$

Pendaftaran adalah proses menjadikan karyawan secara sah menjadi peserta Jamsostek. Pada tahap ini perusahaan mengambil formulir pendaftaran dari PT Jamsostek untuk diserahkan dan diisi karyawan. Setelah formulir diisi, perusahaan menyerahkan formulir tersebut kepada PT Jamsostek dan menyerahkan segala kewajiban agar karyawan resmi terdaftar sebagai peserta Jamsostek pada PT Jamsostek.

Setelah karyawan secara resmi menjadi peserta Jamsostek, perusahaan memotong sejumlah gaji karyawan untuk iuran peserta dan menambahkan/menggabungkan dengan kewajiban dari perusahaan untuk diserahkan kepada PT Jamsostek. Hal ini dilakukan seti- 
ap bulan. Perusahaan secara rutin juga harus mengumumkan berbagai informasi yang datang dari PT Jamsostek, termasuk di antaranya mengenai saldo/rekening koran peserta. Hal ini dilakukan dalam rangka transparansi pelaksanaan program Jamsostek, misalnya dengan menempel informasi di Papan Pengumuman. Kayawan menerima pelayanan sesuai dengan jenis pelayanan atau program yang diikuti. Oleh karena itu, pihak perusahaan senantiasa harus membantu karyawan dalam memperoleh apa yang menjadi haknya sesuai dengan keperluan. Selain itu kemudahan administrasi dan kualitas pelayanan teknis oleh klinik atau rumah sakit atau institusi lain sebagai mitra kerja PT Jamsostek sangat menentukan kualitas pelayanan Jamsostek.

Pelayanan di bidang kesehatan merupakan unsur utama penyelenggaraan Jamsostek karena menyangkut dua dari empat bidang pelayanan Jamsostek. Oleh karena itu, institusi penyelenggara pelayanan kesehatan merupakan ujung tombak utama penentu kualitas penyelenggaraan Jamsostek. Secara umum pelayanan kesehatan yang diberikan seperti Puskesmas masih buruk. Hal ini diketahui dari rendahnya tingkat kepuasan pengguna pelayanan kesehatan. Kondisi seperti ini tidak hanya terdapat pada pelayanan medis, tetapi juga melayanan nonmedis, seperti sikap petugas, kecepatan pelayanan, maupun sarana dan prasarana. ${ }^{19}$

Lebih jauh lagi dapat dikemukakan bahwa kepuasan pelayanan kesehatan adalah hasil dari pengaruh antara keterampilan, pengetahuan, perilaku, sikap, dan penyediaan sarana. Dalam menyatakan kepuasan atau ketidakpuasan terhadap pelayanan kesehatan pasien dan keluarga bergantung pada pengalaman sebelum maupun sesudah menerima pelayanan kesehatan di suatu rumah sakit. ${ }^{20}$

Harus diakui, walau memiliki misi kemanusiaan, penyelenggara pelayanan kesehatan sering mengutamakan pencapaian keuntungan. Hal ini ditunjukkan oleh hasil penelitian tentang kinerja dari sebuah institusi penyelenggara pelayanan kesehatan mata, yang antara lain menyimpulkan pencapaian 100\% kinerja di bidang keuangan, tetapi capaian kinerja di bidang pelayanan terhadap pasien hanya $51 \% .21$

Tingkat kepuasan yang rendah atas pelayanan publik merupakan gejala umum. Hasil penelitian tentang perbandingan tingkat kepuasan peserta asuransi kesehatan wajib dan sukarela terhadap mutu pelayanan kesehatan tingkat I di kota Kendari menunjukkan pelayanan dokter $34,26 \%$ bagi pengguna askes wajib, sedangkan bagi pengguna asuransi kesehatan sukarela $31,00 \%$; peresepan obat $21,67 \%$ bagi pengguna asuransi kesehatan wajib, sedangkan bagi pengguna asuransi kesehatan sukarela $18,76 \%$; sistem rujukan $7,51 \%$ bagi pengguna askes wajib, sedangkan bagi pengguna askes sukarela $6,46 \%$; akses pelayanan $21,46 \%$ bagi pengguna askes wajib, sedangkan bagi pengguna askes sukarela $19,40 \%$; fasilitas lingkungan fisik $24,18 \%$ bagi pengguna askes wajib, sedangkan bagi pengguna askes sukarela $21,81 \% .22$

\section{Metode}

Penelitian ini adalah penelitian deskriptif dengan menggunakan pendekatan kuantitatif yang bertujuan mengetahui tingkat kepuasan karyawan dan keluarganya dalam pelayanan Jamsostek. Penelitian dilakukan di desa Mulyorejo Kecamatan Sunggal Kabupaten Deli Serdang Provinsi Sumatera Utara. Desa Mulyrejo adalah desa industri, di sana terdapat 14 perusahaan swasta yang bergerak di bidang industri. Desa ini terletak di pinggiran kota Medan. Populasi penelitian adalah keluarga karyawan swasta berjumlah 671 keluarga. Sampel penelitian terdiri dari 70 keluarga karyawan yang ditetapkan dengan menggunakan purposive dan quota random sampling berdasarkan perusahaan tempat bekerja. Aspek purposive dalam penarikan sampel adalah untuk memastikan pemenuhan syarat karyawan yang terpilih menjadi sampel, yaitu pernah menerima pelayanan Jamsostek. ${ }^{23}$

Sesuai dengan peraturan perundang-undangan yang berlaku dan dihubungkan dengan proses pelaksanaan Jamsostek, unsur-unsur yang dikaji dalam penelitian ini adalah sosialisasi program Jamsostek; pendaftaran karyawan menjadi perserta Jamsostek; pelaksanaan pelayanan, meliputi jaminan pemeliharaan kesehatan; jaminan kecelakaan kerja; jaminan kematian. Untuk dua pelayanan pertama meliputi semua sampel, sedangkan untuk pelayanan ketiga hanya berlaku untuk 9 sampel. Hal ini dilakukan karena hanya 9 dari 671 populasi yang pernah menerima pelayanan tersebut. Sedangkan Jaminan Hari Tua (JHT) tidak ikut dikaji, karena tidak terdapat populasi yang sudah pernah menerima pelayanan ini.

Untuk mendapatkan data yang benar-benar mampu menggambarkan tingkat kepuasan karyawan (peserta Jamsostek) dalam pelayanan Jamsostek, disusun berbagai indikator yang dapat dijamin keakuratan (validitas) dan kesesuaiannya dengan fakta lapangan (reliabilitas) yang kemudian dituangkan dalam kuesioner sebagai instrumen penelitian. Indikator sosialisasi meliputi waktu pemberian informasi, cara pemberian informasi, kelengkapan informasi, ketersediaan tempat pengumuman dan kelengkapan informasi, dan pemahaman atas informasi. Indikator pendaftaran meliputi: keterlibatan perusahaan dalam pendaftaran, prosedur pendaftaran, dan jangka waktu menjadi peserta. Indikator pelayanan Jaminan Pemeliharaan Kesehatan dan Jaminan Kecelakaan Kerja meliputi: keterlibatan/kepedulian perusahaan tempat bekerja, prosedur administrasi, pelayanan administrasi, kecepatan pelayanan, sikap petugas, kelengkapan obat, kualitas obat dan kualitas pelayanan medis. Indikator pelayanan Jaminan Kematian meliputi keterlibatan/kepedulian perusahaan, prosedur ad- 
Siagian, Tingkat Kepuasan Karyawan dalam Pelayanan Jamsostek

ministrasi, pelayanan administrasi, keutuhan dana yang diterima, dan banyaknya dana yang diterima.

Untuk menjamin validitas dan reliabilitas instrumen penelitian (kuesioner) dengan indikator-indikator yang termuat di dalamnya, kuesioner terlebih dahulu telah diuji coba kepada 15 orang peserta Jamsostek. Hasilnya, alat penjaring data dengan indikator-indikator yang termuat di dalamnya mampu menggambarkan secara akurat (validitas) dan faktual (reliabilitas) tingkat kepuasan peserta dalam pelayanan Jamsostek. Data yang dikumpulkan dianalisis secara statistik deskriptif, sedangkan untuk mengetahui tingkat kepuasan peserta Jamsostek, pengukuran data dilakukan dengan menggunakan skala likert yang terdiri dari tiga kategori atau kelas. Sesuai dengan interval yang diperoleh, maka indikator dari tiga kelas atau kategori tersebut, adalah: -1 s.d. $-0,33$ (tidak puas), $-0,33$ s.d. 0,33 (netral), dan 0,33 s.d. 1 (puas). 24

\section{Hasil}

\section{Sosialisasi Program Jamsostek}

Berdasarkan tabel tingkat kepuasan karyawan sehubungan dengan pelaksanaan sosialisasi program Jamsostek (Tabel 1) didapatkan sebagian besar responden merasa puas dengan waktu pemberian informasi (28 orang). Waktu pelaksanaan sosialisasi program Jamsostek yang dilakukan perusahaan berbeda-beda. Ada perusahaan yang langsung melakukan sosialisasi atau memberikan informasi Jamsostek saat proses perekrutan karyawan seperti saat wawancara, setelah seseorang dinyatakan diterima sebagai karyawan, saat mulai bekerja dengan status percobaan, dan setelah menjadi karyawan tetap. Perbedaan ini mengakibatkan perbedaan dalam tingkat kepuasan karyawan.

Unsur lain yang memengaruhi tingkat kepuasan adalah cara pemberian informasi, yakni bagaimana bagian personalia memberikan informasi program jamsostek. Misalnya, menarik, kurang menarik, atau tidak menarik. Keadaan ini menimbulkan kesan tersendiri kepada karyawan yang membentuk pencitraan dalam bentuk tingkat kepuasan karyawan. Pada penelitian ini cara pemberian informasi bagi responden masih dianggap hal yang biasa (netral).

Kelengkapan informasi tentang program Jamsostek juga beraneka ragam. Terdapat perusahaan yang memberikan informasi secara lengkap, kurang lengkap, atau tidak lengkap. Kondisi ini melahirkan kesan dalam bentuk tingkat kepuasan karyawan. Didapatkan responden penelitian ini kebanyakan merasa puas dengan kelengkapan informasi yang diberikan.

Tabel 1 memperlihatkan tingkat kepuasan karyawan dalam sosialisasi program Jamsostek. Ketersediaan tempat pengumuman dan kelengkapan informasi program Jamsostek tidak mempunyai tingkat kepuasan yang besar bagi responden. Kelengkapan informasi di berbagai perusahaan berbeda-beda. Ada perusahaan yang memiliki media
Tabel 1. Tingkat Kepuasan Karyawan dalam Sosialisasi Program Jamsostek

\begin{tabular}{lcccc}
\hline Kegiatan Sosialisasi & Puas & Netral & Tidak Puas & Jumlah \\
\hline Waktu pemberian informasi & 32 & 27 & 11 & 70 \\
Cara pemberian informasi & 28 & 29 & 13 & 70 \\
Kelengkapan informasi & 41 & 19 & 10 & 70 \\
Ketersediaan tempat pengumuman & 20 & 36 & 14 & 70 \\
dan kelengkapan informasi & 26 & 31 & 13 & 70 \\
Pemahaman atas informasi & 267 & 142 & 61 & 350 \\
\hline Total & 147 & & & \\
\hline
\end{tabular}

berupa papan pengumuman yang berisikan informasi Jamsostek dengan sangat terbatas atau minim, cukup banyak, atau tidak ada. Bahkan ada perusahaan yang sama sekali tidak memiliki papan pengumuman. Kondisi tersebut mengakibatkan tingkat kepuasan yang berbeda-beda bagi karyawan.

Akhirnya, pelaksanaan sosialisasi yang berbeda-beda akan menimbulkan tingkat pemahaman yang berbeda-beda pula, seperti paham, kurang paham atau tidak paham. Kondisi ini menimbulkan tingkat kepuasan yang berbeda-beda bagi karyawan.

Perhitungan skala likert menghasilkan rerata sebesar 0,246 . Hal ini menunjukkan bahwa karyawan dalam kategori "netral", dalam arti tidak termasuk "puas" dan tidak pula termasuk "tidak puas" dalam proses sosialisasi program Jamsostek.

\section{Proses Pendaftaran}

Setelah sosialisasi berlangsung, tahap implementasi program Jamsostek selanjutnya adalah pendaftaran. Tahap ini merupakan proses menjadikan karyawan secara sah menjadi peserta program Jamsostek. Berikut ini disajikan data tingkat kepuasan karyawan berkaitan dengan proses pendaftaran menjadi peserta (Tabel 2).

Kesertaan dalam program Jamsostek adalah hak karyawan. Sedangkan keterlibatan perusahaan dalam proses pendaftaran karyawan sebagai perserta jamsostek beraneka ragam, yang merupakan gambaran proaktif perusahaan, termasuk di dalamnya sejauh mana perusahaan membantu karyawan mempersiapkan berkas yang diperlukan. Hal ini tentu memberikan kesan tersendiri dalam bentuk tingkat kepuasan karyawan.

Unsur lain yang memengaruhi tingkat kepuasan karyawan dalam proses pendaftaran adalah prosedur pendaftaran. Prosedur pendaftaran yang berlaku mungkin saja berbelit-belit atau rumit, atau bahkan sederhana, dan secara khusus memengaruhi sikap dalam bentuk tingkat kepuasan karyawan, seperti langsung mendaftar sejak bekerja atau masa percobaan, saat sudah menjadi karyawan tetap, atau malah dalam jangka waktu tertentu setelah seseorang menjadi karyawan tetap. Jangka waktu yang berbeda tentu akan menimbulkan tingkat kepuasan yang berbeda. 
Tabel 2. Tingkat Kepuasan Karyawan dalam Pendaftaran sebagai Peserta Program Jamsostek

\begin{tabular}{lcccc}
\hline Kegiatan Pendaftaran & Puas & Kurang Puas & Tidak Puas & Jumlah \\
\hline $\begin{array}{l}\text { Keterlibatan perusahaan dalam } \\
\text { pendaftaran }\end{array}$ & 51 & 16 & 3 & 70 \\
$\begin{array}{l}\text { Prosedur pendaftaran } \\
\text { Jangka waktu menjadi peserta }\end{array}$ & 53 & 12 & 5 & 70 \\
\hline Total & 147 & 46 & 17 & 210 \\
\hline
\end{tabular}

Tabel 3. Tingkat Kepuasan dalam Pelayanan Jaminan Pemeliharaan Kesehatan (JPK)

\begin{tabular}{llccc}
\hline Kegiatan Pelayanan JPK & Puas & Kurang Puas & Tidak Puas & Jumlah \\
\hline Keterlibatan/keperdulian & 28 & 20 & 22 & 70 \\
perusahaan & 25 & 19 & 26 & 70 \\
Prosedur administrasi & 11 & 15 & 44 & 70 \\
Pelayanan administrasi & 9 & 12 & 49 & 70 \\
Kecepatan pelayanan & 10 & 14 & 46 & 70 \\
Sikap petugas & 16 & 18 & 36 & 70 \\
Kelengkapan obat & 12 & 15 & 43 & 70 \\
Kualitas obat & 6 & 13 & 51 & 70 \\
Kualitas pelayanan medis & 117 & 126 & 317 & 560 \\
\hline Total & & & & \\
\hline
\end{tabular}

Hasil perhitungan skala likert menghasilkan rerata sebesar 0,619, yang berarti bahwa karyawan dalam kategori "puas" dalam pelaksanaan pendaftaran menjadi peserta Jamsostek.

\section{Pelaksanaan Pelayanan}

\section{Jaminan Pemeliharaan Kesehatan (JPK)}

Tahap selanjutnya dalam implementasi Jamsostek adalah pelaksanaan pelayanan sesuai dengan jenis program yang diikuti. Hasil penghitungan skala likert menghasilkan rerata sebesar $-0,357$, yang berarti bahwa karyawan dalam kategori "tidak puas" dalam pelayanan Jaminan Pemeliharaan Kesehatan (JPK) (Tabel 3).

\section{Jaminan Kecelakaan Kerja (JKK)}

Jaminan kecelakaan adalah unsur sangat penting dalam pelaksanaan Jamsostek. Hasil penghitungan skala likert menghasilkan rerata sebesar -0,416 yang berarti bahwa karyawan dalam kategori "tidak puas" dalam pelayanan Jaminan Kecelakaan Kerja (JKK) sebagai salah satu pelayanan dalam program Jamsostek (Tabel 4).

\section{Jaminan Kematian (JK)}

Jaminan Kematian adalah pelayanan ketiga yang diperoleh peserta Jamsostek. Tingkat kepuasan peserta dalam pelayanan berdasarkan hasil penghitungan skala likert menghasilkan rerata sebesar 0,644 yang berarti bahwa karyawan dalam kategori "puas" dalam pelaksanaan Jaminan Kematian dalam program Jamsostek (Tabel 5).
Tabel 4. Tingkat Kepuasan dalam Pelayanan Jaminan Kecelakaan Kerja (JKK)

\begin{tabular}{llccc}
\hline Kegiatan Pelayanan JKK & Puas & Kurang Puas & Tidak Puas & Jumlah \\
\hline $\begin{array}{l}\text { Keterlibatan/keperdulian } \\
\text { perusahaan }\end{array}$ & 20 & 21 & 29 & 70 \\
Prosedur administrasi & 22 & 18 & 30 & 70 \\
Pelayanan administrasi & 10 & 14 & 46 & 70 \\
Kecepatan pelayanan & 7 & 13 & 50 & 70 \\
Sikap petugas & 11 & 13 & 46 & 70 \\
Kelengkapan obat & 15 & 17 & 38 & 70 \\
Kualitas obat & 12 & 14 & 44 & 70 \\
Kualitas pelayanan medis & 6 & 11 & 53 & 70 \\
\hline Total & 103 & 121 & 336 & 560 \\
\hline
\end{tabular}

Tabel 5. Tingkat Kepuasan dalam Pelayanan Jaminan Kematian (JK)

\begin{tabular}{llccc}
\hline Kegiatan Pelayanan JK & Puas & Kurang Puas & Tidak Puas & Jumlah \\
\hline $\begin{array}{l}\text { Keterlibatan/keperdulian } \\
\text { perusahaan }\end{array}$ & 9 & 0 & 0 & 9 \\
Prosedur administrasi & 6 & 3 & 0 & 9 \\
Pelayanan administrasi & 5 & 3 & 1 & 9 \\
Keutuhan dana yang diterima & 9 & 0 & 0 & 9 \\
Banyaknya dana yang diterima & 3 & 4 & 2 & 9 \\
\hline Total & 32 & 10 & 3 & 45 \\
\hline
\end{tabular}

\section{Pembahasan}

Hasil penelitian menunjukkan bahwa pelaksanaan Jamsostek yang merupakan amanah konstitusi belum memuaskan karyawan dan keluarga sebagai peserta program. ${ }^{8}$ Indonesia saat ini masih memarjinalkan berbagai pelayanan publik baik bagi karyawan maupun kaum miskin lainnya. Padahal, karyawan adalah pemegang kunci yang memiliki kontribusi besar dan strategis dalam proses produksi, sehingga seharusnya kebutuhan mereka dapat terpenuhi dengan baik, termasuk di dalamnya semua jenis pelayanan yang terdapat dalam Jamsostek mendapat perhatian besar dan sungguh-sungguh, antara lain diwujudkan melalui pelaksanaan Jamsostek yang baik. 1,2,9 Tidak berlebihan jika dikemukakan bahwa tingkat pertumbuhan ekonomi suatu negara, termasuk Indonesia signifikan dengan kontribusi karyawan di perusahaan tempat bekerja masing-masing.

Secara teoretis, program Jamsostek sebagai salah satu program dalam sistem jaminan sosial nasional menguntungkan pihak perusahaan. Dengan adanya Jamsostek, tenaga kerja akan merasa nyaman dalam bekerja, sehingga dapat menyumbangkan keahliannya secara maksimal dalam proses produksi melalui operasionalisasi ilmu pengetahuan dan teknologi, yang pada gilirannya akan meningkatkan produktivitas. ${ }^{3}$ Peningkatan produktivitas tentu menguntungkan perusahaan. Kaitan langsung antara perasaan nyaman tenaga kerja dalam bekerja, produktivitas tenaga kerja, dan keuntungan perusahaan semestinya menjadikan pihak perusahaan melakukan ino- 
vasi dan kreasi dalam penciptaan dan pelaksanaan jaminan sosial bagi tenaga kerjanya. Dengan demikian, inisiatif negara dalam menetapkan Jamsostek sebagai hak tenaga kerja merupakan kebijakan publik yang menguntungkan perusahaan. ${ }^{9}$ Lebih dalam lagi, sistem jaminan sosial yang pertama kali dikemukakan merupakan inisiatif negara dalam rangka menciptakan kondisi yang kondusif dalam proses produksi dengan jalan mengurangi beban perusahaan dalam menjalankan kewajibannya. ${ }^{6,10}$ Namun, manajemen perusahaan ternyata kurang menyadari sisi positif yang demikian besar dari pelaksanaan Jamsostek terhadap perusahaan. Hal ini diketahui dengan pelaksanaan sosialisasi program Jamsostek yang kurang baik, dalam arti belum memuaskan pihak karyawan (menurut ukuran skala likert hanya dalam kategori "netral", dengan rerata 0,246). Padahal, dari semua tahap pelaksanaan Jamsostek, sosialisasi merupakan tahapan perusahaan terlibat $100 \%$. Dengan demikian, kualitas pelaksanaan sosialisasi sepenuhnya bergantung pada perusahaan tempat karyawan bekerja. Seandainya pihak perusahaan tidak memiliki sumber daya manusia yang andal dalam melaksanakan sosialisasi, pihak manajemen perusahaan dapat bekerja sama dengan PT Jamsostek dalam rangka pelaksanaan sosialisasi program Jamsostek. ${ }^{18}$

Proses pendaftaran karyawan menjadi peserta Jamsostek melibatkan dua institusi, yaitu perusahaan tempat karyawan bekerja dan PT Jamsostek. Sebagai pihak yang ditunjuk negara sebagai penyelenggara Jamsostek. ${ }^{13}$ PT Jamsostek menetapkan prosedur pendaftaran karyawan menjadi peserta Jamsostek. Dengan tingkat pendidikan mayoritas tenaga kerja di Indonesia yang masih rendah tentu diperlukan birokrasi yang sederhana, sehingga memudahkan karyawan dalam mengisi formulir dan mendaftarkan diri di kantor PT Jamsostek terdekat. ${ }^{16}$ Untuk lebih memudahkan karyawan dalam mendaftarkan diri sebagai peserta Jamsostek, maka bantuan dari bagian personalia perusahaan tempat mereka bekerja sangat diperlukan. Hasil penelitian menunjukkan bahwa karyawan merasa puas dalam proses pendaftaran menjadi peserta Jamsostek (menurut ukuran skala likert dalam kategori "puas", dengan rerata 0,619). Kepuasan ini merupakan kontribusi dari prosedur yang ditetapkan PT Jamsostek yang cukup sederhana, sikap proaktif perusahaan tempat karyawan bekerja dalam membantu karyawan memberi penjelasan dalam pengisian formulir, memenuhi persyaratan serta mendaftarkan diri, dan kontribusi perusahaan tempat karyawan bekerja dalam mengupayakan karyawannya menjadi peserta Jamsostek sedini mungkin.

Setelah berlangsungnya tahap sosialisasi dan pendaftaran, pelaksanaan Jamsostek memasuki tahap substansi, yakni pelayanan. Jaminan Pemeliharaan Kesehatan (JPK) merupakan salah satu dari empat pelayanan yang tersedia dalam Jamsostek, dan salah satu dari tiga jenis pelayanan yang dijadikan objek penelitian ini. ${ }^{9}$ Pemeliharaan kesehatan merupakan pelayanan publik yang sangat penting. Seperti dikemukakan Zastrow, pemeliharaan kesehatan merupakan bagian dari empat usaha atau pelayanan yang dilakukan dalam mewujudkan kesejahteraan sosial. ${ }^{5}$ Pemeliharaan kesehatan merupakan kebutuhan mutlak bagi buruh di seluruh dunia, seperti halnya kaum miskin lain tidak memiliki akses jika pemeliharaan kesehatan hanya dapat dipenuhi melalui mekanisme pasar. Oleh karena itu, pelayanan pemeliharaan kesehatan melalui program Jaminan Sosial merupakan usaha kreatif dalam upaya memenuhi kebutuhan buruh yang dapat memengaruhi tingkat kepuasan karyawan kesehatan.

Demikian halnya dengan prosedur administrasi yang harus dilalui untuk memperoleh pemeliharaan kesehatan memberikan pengaruh terhadap tingkat kepuasan karyawan. Sikap petugas administrasi mitra kerja PT Jamsostek dalam bentuk unit pelayanan teknis berupa rumah sakit, klinik maupun pusat pelayanan kesehatan lainnya akan memengaruhi tingkat kepuasan karyawan dalam pelayanan Jamsostek. Kecepatan pelayanan tentu merupakan bagian penting dalam proses memperoleh pelayanan kesehatan. Bagaimanapun juga, semua pihak ingin diberikan pelayanan secara cepat karena berkaitan dengan nyawa. Dengan demikian kecepatan ini tentu memengaruhi tingkat kepuasan karyawan dalam pelayanan Jamsostek. Sikap tersebut merupakan gambaran apresiasi petugas rumah sakit dan mitra kerja PT Jamsostek terhadap pasien, yang selanjutnya memengaruhi tingkat kepuasan karyawan dalam pelaksanaan Jamsostek.

Sangat disayangkan, pelayanan yang demikian penting ini ternyata tidak berjalan dengan baik. Menurut ukuran skala likert hasil penelitian menunjukkan bahwa karyawan dalam kategori "tidak puas" dengan rerata 0,357. Lebih dalam lagi, dari berbagai indikator pelayanan kesehatan ini, kondisi paling buruk justru terdapat pada hal yang bersifat teknis substansial, yakni kualitas pelayanan medis. Kondisi pelayanan yang buruk juga terdapat pada indikator penting lainnya, seperti kecepatan pelayanan, sikap petugas, kualitas obat, kelengkapan obat, bahkan pelayanan administrasi. Pelayanan yang tidak terlalu buruk hanya terdapat pada indikator keterlibatan/kepedulian perusahaan dan prosedur administrasi. Hal ini berarti, bahwa PT Jamsostek sudah berupaya menetapkan prosedur administrasi yang cukup sederhana, namun pelaksanaan di lapangan mengalami bias. Kondisi ini senada dengan prinsip yang sering diterapkan birokrat berperilaku buruk: "jika bisa dipersulit, mengapa harus dipermudah”. Pelayanan kesehatan di Indonesia masih tergolong pelayanan publik yang buruk atau tidak memuaskan. Hasil penelitian ini identik dengan hasil penelitian tentang perbandingan tingkat kepuasan peserta asuransi kesehatan wajib dan 
sukarela terhadap mutu pelayanan kesehatan tingkat I di kota Kendari oleh Agna, Hendrartini dan Margo, kondisi buruk terjadi di semua unsur pelayanan. ${ }^{22}$ Kondisi ini menunjukkan perlunya pemberdayaan tenaga kesehatan, baik dalam hal keterampilan, pengetahuan, perilaku, maupun sikap. ${ }^{20}$

Hasil penelitian selanjutnya menginformasikan bahwa pelayanan pada Jaminan Kecelakaan Kerja lebih buruk. Menurut ukuran skala likert hasil penelitian menunjukkan bahwa karyawan adalah dalam kategori "tidak puas" memiliki rerata 0,416. Kondisi paling buruk dalam pelayanan Jaminan Kecelakaan Kerja justru terdapat pada pelayanan yang paling substansial, yakni pada kualitas pelayanan medis dan kecepatan pelayanan. Bagaimanapun juga, bagi korban kecelakaan kerja, kecepatan pelayanan dan kualitas pelayanan medis sangat menentukan keselamatan nyawa. Kondisi buruk ini diikuti pelayanan administrasi, sikap petugas, kualitas obat, dan kelengkapan obat. Melihat kondisi ini, tidak keliru jika dinyatakan bahwa Jaminan Pemeliharaan Kesehatan, pelayanan Jaminan Kecelakaan Kerja secara keseluruhan masih buruk. Hal ini berarti tidak memandang jenis atau item pelayanannya dan siapa pelaku pelayanan itu, pelayanan yang berkaitan dengan kesehatan sebagai kebutuhan utama manusia masih tergolong buruk. ${ }^{17,19-22}$

Berbeda dengan tahap dan jenis pelayanan Jamsostek lainnya, pelaksanaan Jaminan Kematian sebagai salah satu jenis pelayanan dalam Jamsostek tergolong baik, ${ }^{9}$ dalam arti bahwa pihak keluarga sebagai pihak penerima pelayanan secara umum merasa "puas" dengan hasil skala likert 0,644. Khusus dalam item keterlibatan/kepedulian perusahaan dan keutuhan dana yang diterima semua responden menyatakan puas, sedangkan untuk prosedur administrasi, tidak seorang pun responden menyatakan "tidak puas", namun masih terdapat tiga orang responden yang menyatakan "kurang puas". Untuk pelayanan administrasi, selain terdapat tiga orang responden yang menyatakan "kurang puas", ternyata terdapat satu orang responden yang menyatakan "tidak puas". Hal ini berarti, meskipun pihak PT Jamsostek telah berupaya menyederhanakan prosedur administrasi, namun sikap petugas tidak selalu mendukung pelayanan yang baik dan sederhana. ${ }^{20}$ Hal yang tidak kalah penting dari hasil penelitian ini, meskipun santunan kematian yang diberikan oleh PT Jamsostek kepada keluarga secara utuh, pihak keluarga ternyata "kurang puas" atas jumlahnya. Hal ini menuntut perhatian dari pemangku kepentingan, pengambil, dan pelaksana kebijakan yang berkenaan dengan jumlah santunan kematian. Sikap yang ditunjukkan peserta Jamsostek ini tentu dapat dipahami, mengingat mereka kehilangan anggota keluarga yang selama ini bertanggung jawab atas sosial ekonomi keluarga.

Berdasarkan hasil penelitian yang telah dikemukakan dapat diketahui bahwa kelemahan pelaksanaan Jamsostek terutama terletak pada pelaku pelayanan di lapangan, yaitu mitra kerja PT Jamsostek, seperti rumah sakit, klinik, apotik, optik dan lain-lain sebagai ujung tombak pelayanan. Hal ini berarti bahwa PT Jamsostek belum selektif dalam memilih institusi yang menjadi mitra kerja. ${ }^{15}$ Di samping itu, PT Jamsostek sebagai pelaku monopoli pelaksanaan Jamsostek mungkin tidak melakukan pengawasan melekat atas pekerjaan mitra kerjanya dalam rangka pelaksanaan Jamsostek. Meskipun PT Jamsostek bukanlah pelaku langsung dari buruknya pelayanan Jamsostek, perusahaan milik negara ini adalah pihak yang bertanggung jawab penuh atas buruknya pelaksanaan Jamsostek. ${ }^{14}$

\section{Kesimpulan}

Hasil analisis data tentang tingkat kepuasan karyawan swasta dan keluarga peserta Jamsostek mendapatkan lima unsur implementasi pelayanan yang dinilai antara lain yaitu sosialisasi program dalam kategori "netral" untuk proses pendaftaran, kategori "puas" untuk pelayanan Jaminan Kematian, dan 2 pelayanan dalam kategori "tidak puas", yaitu Jaminan Pemeliharaan Kesehatan dan Jaminan Kecelakaan Kerja. Jika dicari rerata untuk semua kegiatan, diperoleh angka 0,146 yang berarti bahwa secara menyeluruh tingkat kepuasan karyawan/keluarga peserta Jamsostek dalam kategori "netral”. Kondisi ini di antara puas dan tidak puas, yang identik dengan "kurang puas". Hal ini menunjukkan bahwa pelaksanaan program tersebut belum baik.

Jika dikaji secara khusus unsur kegiatan yang memberikan kontribusi negatif terhadap tingkat kepuasan dalam pelaksanaan program Jamsostek tersebut, dapat diketahui bahwa kontributor berasal dari mitra kerja PT Jamsostek, seperti rumah sakit maupun klinik. Titik lemahnya terutama pada pelayanan administrasi, kecepatan pelayanan, sikap petugas, kelengkapan obat, kualitas obat, dan kualitas pelayanan medis. Unsur kegiatan ini justru bersifat substansial.

\section{Saran}

Perusahaan harus lebih proaktif dalam memberikan keberhasilan pelaksanaan program Jamsostek, antara lain dengan melakukan sosialisasi sejak dini kepada karyawan sejak seseorang diterima bekerja dan belum mulai bekerja di perusahaan. Bagian SDM dalam setiap perusahaan harus dilatih secara khusus agar benar-benar memahami program Jamsostek dan mampu memberikan informasi yang komprehensif kepada karyawan.

Sebagai pelaksana resmi program Jamsostek, PT Jamsostek harus lebih selektif dalam memilih mitra kerja, seperti rumah sakit, klinik, balai pengobatan, dan institusi lain yang merupakan ujung tombak dalam pelaksanaan program Jamsostek, sehingga mampu memberikan pelayanan administrasi dan teknis yang baik dengan prosedur yang sederhana, sehingga peserta Jamsostek merasa puas atas pelayanan yang diberikan. 


\section{Daftar Pustaka}

1. Simanjuntak P. Undang-undang yang baru tentang serikat pekerja/serikat buruh. Jakarta: Kantor Perburuhan Internasional; 2005.

2. Sinaga M. Kesehatan kerja pada pramuniaga. The Journal of Public Health. 2005; 9 (1): 33.

3. Mahyuni EL. Evaluasi penerapan sikap kerja 5-s dalam meningkatkan produktivitas perusahaan di PT. ABC tahun 2005. The Journal of Public Health. 2006; 10 (1): 74-5.

4. Gofin J, Gofin R, Neumark Y. The Jerusalem experience: three decades of service, research, and traning in community primary care. American Journal of Public Health. 2002; 92 (11): 1717-21.

5. Zastrow C. Introduction to social work and social welfare. Belmont: Thomson Brokks; 2008.

6. Sulastomo. Sistem jaminan sosial nasional sebuah introduksi. Jakarta: Rajawali Press; 2008

7. Mudiyono. Jaminan sosial di Indonesia: relevansi pendekatan informal. Jurnal Ilmu Sosial dan Ilmu Politik. 2002; 6 (1): 68.

8. Pakpahan R, Sihombing E. Tanggung jawab negara dalam pelaksanaan jaminan sosial. Jurnal Legislasi Indonesia. 2012; 9 (2): 169.

9. Manullang S. Pokok hukum ketenagakerjaan Indonesia. Jakarta: PT. Rineka Cipta; 2005.

10. Lubis, D. Penyelenggaraan jaminan pemeliharaan kesehatan oleh PT. Asuransi kesehatan dan PT. Jamsostek. Jurnal Wawasan. 2007; 13 (2): 154.

11. Harian Umum Pelita Online. 21 Januari 2009 [cited 2010 Jun 30]. Available from: http://www.hupelita.com/baca.php?id= 63654 .

12. Retnaningsih E, Misnaniarti, Aini A. Kajian kelayakan badan layanan iuumum dan alternatif bentuk penyelenggaraan jamsostek Sumatera Selatan semesta sesuai undang-undang sistem jaminan sosial nasional. Jurnal Manajemen Pelayanan Kesehatan. 2012; 15 (1): 20-21.
13. Wijayanti A. Reformasi hukum dalam penyelenggaraan jamsostek bagi pekerja swasta. Jurnal Electronic UM Surabaya. 2007; 1 (1): 2.

14. Rahman A. Mengukur kepuasan pelayanan institusi pemerintah: studi kasus pada BUMN PT. Jamsostek. Jurnal Ilmu Administrasi. 2009; 7 (2): 228.

15. Basjir W. Informalisasi, jaminan sosial, dan pengorganisasian buruh. Jurnal Analisis Sosial. 2003; 8 (8): 44.

16. Suparjan. Jaminan sosial berbasis komunitas: respon kegagalan negara dalam penyediaan jaminan kesejahteraan. Jurnal Ilmu Sosial dan Ilmu Politik. 2010; 13 (3): 2-3.

17. Kodim N. Pelayanan jamsostek seharusnya mulia, bukan basa-basi. Medika (Jurnal Kedokteran Indonesia). 2009; 35: 1.

18. Wahab Z. Dana pensiun dan jaminan sosial tenaga kerja di Indonesia. Bandung: PT. Citra Aditya Bakti; 2002.

19. Azkha N, Elnovriza D. Analisis tingkat kepuasan klien terhadap pelayanan kesehatan di puskesmas dalam wilayah Kota Padang tahun 2006. Jurnal Kesehatan Masyarakat. 2007; 1 (2): 57.

20. Widujani I, Mukti A, Hendrartini. Hubungan besaran iuran biaya dengan kepuasan peserta askes di RSU Wangaya. Jurnal Manajemen Pelayanan Kesehatan. 2004; 7 (3): 142.

21. Purnamanita, Pasiniring S, Maidin A. Kinerja balai kesehatan mata masyarakat Makassar dengan perspektif Balanced Score Card. Jurnal Manajemen Pelayanan Kesehatan. 2012; 15 (2): 51.

22. Aga N A, Hendrartini J, Margo V. Perbandingan tingkat kepuasan peserta askes wajib dan sukarela terhadap mutu pelayanan kesehatan tingkat I. Jurnal Manajemen Pelayanan Kesehatan. 2005; 8 (4): 186.

23. Siagian M. Metode Penelitian sosial pedoman praktis penelitian bidang ilmu-ilmu sosial dan kesehatan. Medan: Grasindo Monoratama; 2010.

24. Bungin B. Metodologi penelitian kuantitatif. Jakarta: Kencana Prenada Media Group; 2006. 